\title{
Growth, photosynthesis and some related metabolites as suitable selection criteria for the copper tolerance of Ankistrodesmus falcatus.
}

\author{
Zeinab A. Ahmed ${ }^{1}$, Magdy A. Abo- Gharbia ${ }^{1}$, Asmaa B. Ahmed ${ }^{1}$ \\ ${ }^{1}$ Department of Botany, Faculty of Science, Sohag Univeristy, Egypt.
}

Rec. 17 Nov, 2011 Accpt. 12 Dec, 2011

\begin{abstract}
:
This investigation was conducted to study the effects of copper on growth and metabolism of Ankistrodesmus falcatus isolated from sewage water at El-Dare Treatment Plant. The alga was grown in BG-11 medium containing different cu concentrations $(0.0,0.5,5,10,50,100$, 150,200 and $250 \mu \mathrm{m} \mathrm{Cu}^{+2}$ ). The test organism was left to grow for 12 days under the various cu levels. The effect of copper on the growth, photosynthetic pigments, protein metabolism (soluble, insoluble), antioxidant compounds (phenolic, Proline) were determined. The cell number and dry weight were increased highly significantly up to $10 \mu \mathrm{m} \mathrm{cu}^{+2}$ ), then the cell number and dry weight reduced gradually by increasing the doses of the copper .The concentration of photosynthetically active pigment peaked up to $10 \mu \mathrm{m} \mathrm{cu}^{+2}$ ), Then they remained more or less unchanged up to $50 \mu \mathrm{m} \mathrm{cu}^{+2}$ ), after this it was reduced. The content of soluble carbohydrates decreased dramatically up to $10 \mu \mathrm{m} \mathrm{cu}^{+2}$, and then it was increased smoothly as the cu concentration increased in culture media. $\mathrm{Cu}$ Stress induced a significant changes in the soluble protein up to the level of $10 \mu \mathrm{m} \mathrm{Cu}^{+2}$, then a high significant accumulation was obtained which peaked at the highest concentration of $\mathrm{Cu}^{+2}(250 \mu \mathrm{m})$. The insoluble and total proteins remained more or less unchanged at the all $\mathrm{Cu}$ concentration used. Aminoacids content accumulated progressively and irregularly by cu treatment. While proline content decreased by about $65.6 \%$ at the level of $10 \mu \mathrm{m} \mathrm{cu}^{+2}$ concentration. It is on other hand increased by $261.7 \%$ at the level of $250 \mu \mathrm{m} \mathrm{cu}^{+2}$ in relation to control value. Phenolic compounds seemed to be not affected by copper treatment.
\end{abstract}

Keyword: Cu toxicity- oxidative stress - Ankistrodesmus falcatus

\section{Introduction:}

Heavy metal contamination of soil is a serious problem for the enviromment. Some metals are required for plant growth and development, but some of these metals are very toxic at high concentration (Rout and Das, 2003; Broadley et al., 2007). Various sources of $\mathrm{Cu}+2$ including industrial and domestic wastes, agricultural practices, copper mine drainage, copper-based pesticides, have contributed to a progressive increase in copper concentrations in varied environments ( Ma et al., 2003 and Andrade et al., 2004). Copper can be good and evil to algae as it is an essential micronutrient for algal growth, participating an important biological reactions as an enzymatic cofactor and electron carrier in the photosynthetic and respiratory processes (Andrade et al., 2004). but at high concentration, it becomes highly toxic (Dewez et al., 2005). Growth inhibition and chlorosis are common symptoms of metal phyto-toxicity in several algae, in which photosynthesis is probably the most affected metabolic process. Copper reduces growth as well as photosynthetic and respiratory activities (Nale-wajko and Olaveson, 1995, Ali et al., 2006).The photosynthetic apparatus is particularly susceptible to this cation, resulting in a decrease in the activity of photo-system 11 and electron transfer rate (Fernade and Henriques, 1991; Malick and Mohn, 2003 and Perales-Vela et al., 2007). Because of its redox properties, copper induces oxidative stress by generating reactive oxygen species like superoxide and hydroxyl radicals via Haber-Weiss and Fenton reactions. Toxicity of cupper might also result from the oxidation of sulphydryl groups of enzymes leading to their inhibition (Teisscire and Guy, 2000). Oxidative stress directly

\footnotetext{
* Corresponding author:

Dr. Zeinab A. Ahmed

$凶$ zeinab_ahmed_2007@yahoo.com
} 
damages proteins, amino acids, nucleic acid, and membrane lipids often leading to alterations in cell structure and mutagenesis (Nagalakshmi and Prasad,1988).Under acute conditions, however, the toxic effects of the pollutants may overwhelm the antioxidant defenses .This may result in cell death or the shut down of all cellular machinery. Toxicity may result in diverse effects, which depend on the type of algae, the nature and concentration of the metal, and the environmental conditions accompanying heavy metal stress (Satoh et al., 2005).The aim of this investigation was to study the effects of different concentrations of $\mathrm{Cu}$ on growth and some related metabolites of Ankistrodesmus falcatus isolated from sewage water at El-Dare Treatment plant. This organism is unicellular green alga which can provide important information on the toxic effects of a pollutant on general metabolic processes and often used as an indicator of contamination.

Material and methods:

Algal species and culturing:

Ankistrodesmusfalcatus was isolated from sewage water at El-Dare Treatment plant at Sohag district, Egypt. The alga was grown in Bold's basal medium according to (Bischoff and Bold, 1963). under the conditions of fluorescent illumination (2500 lux) and room temperature $(25 \pm 2)$. Filtered dry air was allowed let to bubble in the culture vessels to provide carbon dioxide and to prevent settling of algal cells. In this experiment, the algae was grown in BG-11 medium containing different copper concentrations $(0.0,0.5,5,10,50,100,150$, 200 and $250 \mu \mathrm{m} \mathrm{CU}^{+2}$.) For 12 days at the same conditions mentioned above. Each treatment was made in three replicates. At the end of incubation period, the algal cells were harvested and used for growth and metabolic determinations.

Determination of growth parameters:

While was used for isolation of eukaryotic and green algae.

\section{Cell number:}

The cell count of control and treated cultures was measured by Hemacytometer, $0.1 \mathrm{~mm}$ deep, having improved Naubauer ruling (A.O. Spencer "Bright fine"). The count was expressed as cells / $\mathrm{ml}$ algal suspension.

\section{Dry weight:}

Dry weight was determined according to (Utting, 1985). by filtering Culture aliquots $(50 \mathrm{~mL})$ through Whatman GF/C filters. The filters were dried and weighed.

\section{Photosynthetic pigment extraction:}

Chlorophyll a, b and Caroteniod were extracted in $100 \%$ methanol at $65^{\circ} \mathrm{C}$ and their contents were determined spectrophotometrically (SPEKOL 11, CARL ZEISS, JENA, GERMANY) according to (Metzner et al., 1965).

\section{Biochemical determinations: \\ Carbohydrate content estimation:}

Carbohydrate content was determined in aqueous (soluble carbohydrate) and in $\mathrm{HCl}$ solutions (total carbohydrate) with anthrone sulphuric acid reagent according to (Fales, 1951). using glucose as a standard. The blue green color developed was measured at the $620 \mathrm{~nm}$ using spectrophotometer.

\section{Estimation of total free amino acids:}

Total free amino acids were determined according to (Moore et al., 1958). The quantity of total free amino acids was calculated as $\mu \mathrm{gm} / \mathrm{mg}$. dry weight.

\section{Estimation of proline:}

Free proline content of algal suspension was determined according to (Bates et al., 1973). Briefly, $10 \mathrm{~mL}$ of algal suspension was centrifuged and the pellete was extracted in $5 \mathrm{~mL}$ of aqueous $3 \%$ sulfosalicylic acid for $3 \mathrm{~h}$. The extract was centrifuged at 4000 $\mathrm{rpm}$ for $10 \mathrm{~min}$. Two $\mathrm{mL}$ of the supernatant were mixed with $2 \mathrm{ml}$ of fresh acid ninhydrin solution and $2 \mathrm{~mL}$ glacial acetic acid in a test tube for $1 \mathrm{~h}$ at $100 \square$. The tubes were cooled, and the mixture was extracted with $4 \mathrm{~mL}$ toluene. The extract was vigorously stirred for 20 seconds. Therefore, the chromophorecontaining toluene was aspirated from the aqueous phase, and its absorbance was measured at $520 \mathrm{~nm}$. Proline was used as a standard.

\section{Protein content estimation:}

Protein content was determined according to (Lowry et al., 1951). The alga of $10 \mathrm{~mL}$ of algal suspension was extracted in distilledwater (soluble protein) and in $\mathrm{NaOH}$ (Total protein) for $2 \mathrm{~h}$ at $90^{\circ} \mathrm{C}$. The extract was centrifuged and the supernatants were pooled. The water-soluble protein was estimated by the Folin-phenol reagents and measured spectrophotometrically (SPEKOL 
11, CARL ZEISS, JENA, GERMANY.) Bovine serum albumin was used as a standard.

\section{Determination of phenolic compounds:}

Phenolic compounds content was determined according to (Dai et al., 1994). $0.1 \mathrm{gm}$ of fresh tissue. Algal samples were homogenized with a plastic pestle in an Eppendorf tube containing $1 \mathrm{ml}$. phosphate buffer $0.1 \mathrm{M} \mathrm{pH}=7.0$. The homogenate was centrifuged in an Eppendorf microcentrifuge at 12800 for $10 \mathrm{~min}$. Aliquots of $50 \mu \mathrm{L}$. were added to a reaction mixture containing $3 \%$ of sodium carbonate and o.3 M Folin reagent in a final volume of $1 \mathrm{ml}$. The reaction mixture was incubated for $2 \mathrm{hr}$. at room temperature and the absorbance at 765 nm. Total phenolic compounds were expressed as Nan equivalents of Gallic acid using a calibration curve prepared with 10-50 $\mu \mathrm{M}$ of Gallic acid.

\section{Nitrate reductase assay in vivo:}

For in vivo assay of nitrate reductase, the method of (Jaworski, 1971). was used. Algal cells of $10 \mathrm{ml}$ algal suspension of diurontreated alga and untreated were precipitated and incubated in anaerobic dark conditions for $1 \mathrm{~h}$ in $5 \mathrm{ml}$ of $0.1 \mathrm{M} \mathrm{K}$-phosphate $(\mathrm{ph}=7.5)$ containing $50 \mathrm{~mm} \mathrm{KNO3}$ and $1 \%$ (v/v) n-propanol at $28{ }^{\circ} \mathrm{c}$. The reaction was stopped by boiling in water bath for $5 \mathrm{~min}$ and then centrifuged. The supernatant of one $\mathrm{ml}$ sample mixed well with two $\mathrm{ml} 1 \% \mathrm{w} / \mathrm{v}$ sulphonilamide in $1 \mathrm{~N}$ hcland two $\mathrm{ml} 0.1 \%$ w/v N- (1- naphthyl) ethylenediaminedihydrochloride in distilled water. The absorbance was measured by using spectrophotometer (SPEKOL 11, CARL ZEISS, JENA, GERMANY) at 540 $\mathrm{nm}$. Nitrate reductase activity was expressed as $\mu \mathrm{g} \mathrm{NO} 2 / \mathrm{ml}$ algal suspension $\mathrm{h}-1$.

\section{Results:}

The prelaminary data showed that the growth of Ankistrodesmus falcatus completely died beyond $250 \mu \mathrm{m} \mathrm{cu}+2$.The data in Fig (1) revealed that, The cell number and dry weight were increased highly significantly up to $10 \mu \mathrm{mcu}^{+2}$, Then the growth criteria decreased gradually by the further increase in the cu. The harmful effect of $\mathrm{Cu}$ was much more pronounced at the higher doses $(200 \mu \mathrm{M}$ cu+2 and $250 \mu \mathrm{M}$ $\left(\mathrm{cu}^{+2}\right)$. In a conformity the photosynthetic pigments also stimulated up to the level 10 $\mu \mathrm{M} \mathrm{Cu}{ }^{+2}$, Then they remained more or less unchanged up to $50 \mu \mathrm{m} \mathrm{cu}^{+2}$, then a gradual reduction in photosynthetic pigments was obtained which was much more obvious at the highest level of the $\mathrm{cu}\left(200 \mu \mathrm{M} \mathrm{cu}^{+2}\right.$ and $250 \mu \mathrm{M} \mathrm{cu}^{+2}$ ).

the content of soluble carbohydrates decreased dramatically up to $10 \mu \mathrm{m} \mathrm{Cu}{ }^{+2}$, then it increased smoothly as the cu concentration increased in culture media. The highest reduction was recorded at the level of $10 \mu \mathrm{M} \mathrm{Cu}^{+2}$ (about55.3\%) while the highest increase was observed at the higher concentration of cu (9\% over the control value), the insoluble fraction increased progressively up10 $\mu \mathrm{M} \mathrm{Cu}+2$, then It remained more or less unchanged, with a general tendency to decrease especially at the higher level of $\mathrm{Cu}$. The reduction was not exceeded than $9 \%$ at the level of $250 \mu \mathrm{M}$ $\mathrm{Cu}^{+2}$. Consequently the total carbohydrate remained around those of control even at the highest concentration of $\mathrm{Cu}$.

cu stress induced insignificant changes in the soluble protein up to the level of $10 \mu \mathrm{m}$ $\mathrm{Cu}^{+2}$, then a high significant accumulation was obtained which peaked at the highest concentration of $\mathrm{Cu}\left(250 \mu \mathrm{M} \mathrm{cu}{ }^{+2}\right)$ it was increased by $32.97 \%$ over the control at the level of $250 \mu \mathrm{M} \mathrm{Cu}^{+2}$.the insoluble and total proteins remained more or less unchanged at the all $\mathrm{Cu}$ concentration level used.

Aminoacids content accumulated progressively and irregularly by $\mathrm{cu}$ treatment. The highest accumulation was recorded at the level of $50 \mu \mathrm{M} \mathrm{cu}^{+2}(149.24 \%$ over the control), and the lowest accumulation was reported at the lower levels $\left(0.5\right.$ and $\left.5 \mu \mathrm{M} \mathrm{Cu}^{+2}\right)$.

proline content decreased dramatically up to $10 \mu \mathrm{M} \mathrm{cu}^{+2}$ then a sharp and quick accumulation was exhibited beyond these level and continue to be increased as the cu increased in the culture media. Thus while proline content decreased by about $65.6 \%$ at the level of $10 \mathrm{Cu}^{+2}$ concentration. It is on other hand increased by $261.7 \%$ at the level of $250 \mu \mathrm{M} \mathrm{cu}^{+2}$ in the relation to control. The activity of nitrate reductase increased slightly up to $5 \mu \mathrm{M} \mathrm{Cu}^{+2}$, then a sharp increase in the activity was recorded at the level of $10 \mu \mathrm{M}$ $\mathrm{Cu}^{+2} .(174,03 \%$ of control), there after it decreased highly significantly as the cu concentration increased in the culture media. 
This reduction was much more oblivious at the higher doses of cu. At the level of 250 $\mu \mathrm{M} \mathrm{cu}{ }^{+2}$, the percent reduction was about $56 \%$ in relation to the control value.

cu stress did not affected the concentration of phenolic compounds even at the highest concentration of cu. The content of phenolic compound remained mostly around those of control.

Copper stress resulted in the appearance of new polypeptides bands, consequently while the number of polypeptides in control was 15 polypeptides, they were 35 at $250 \mu \mathrm{m}$ $\mathrm{cu}^{+2}$ (more than 2 folded which fluctuated between the low molecular weight polypeptides to the high molecular weight polypeptides. For example 37,34 K Da and $22 \mathrm{~K}$ Da polypeptide appeared only under copper stress also the higher molecular weight polypeptides $(208 \mathrm{~K}$ Da to $71 \mathrm{~K}$ Da)appeared only in copper treated Ankistrodesmus falcatus.

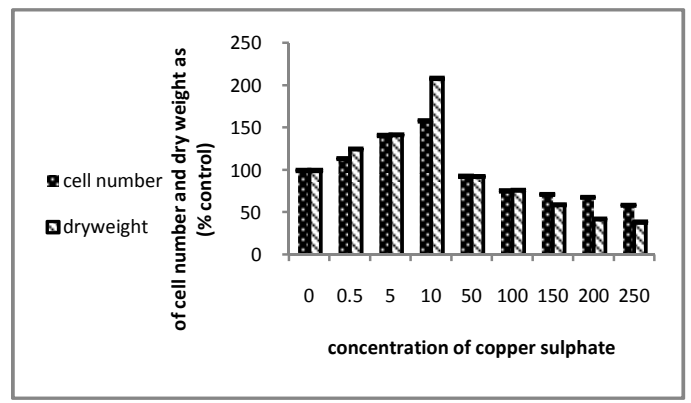

Fig. (1): Effect of different concentrations of cupper ion on the percentage control of cell number and dry weight as (\%control) of Ankistrodesmus falcatus.

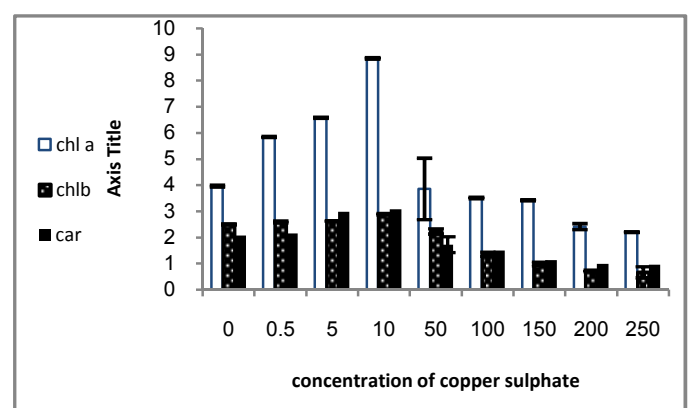

Fig. (2): Effect of different concentration of cupper ion on photosynthetic pigmentschlorophyll a, chlorophyll $b$ and carotenoides (mg/ g fresh weight) of Ankistrodesmus falcatus

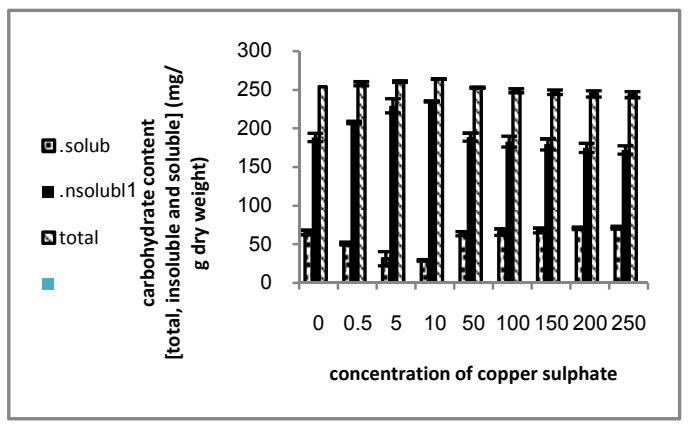

Fig. (3): Effect of different concentrations of cupper ion on the percentage control of carbohydrate contents of Ankistrodesmus falcatus.

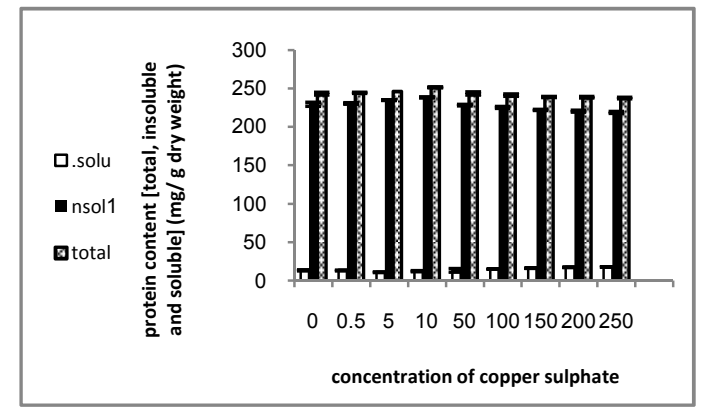

Fig. (4): Effect of different concentrations of cupper ion on protein content [total, insoluble and soluble] (mg/ g dry weight) of Ankistrodesmus falcatus.

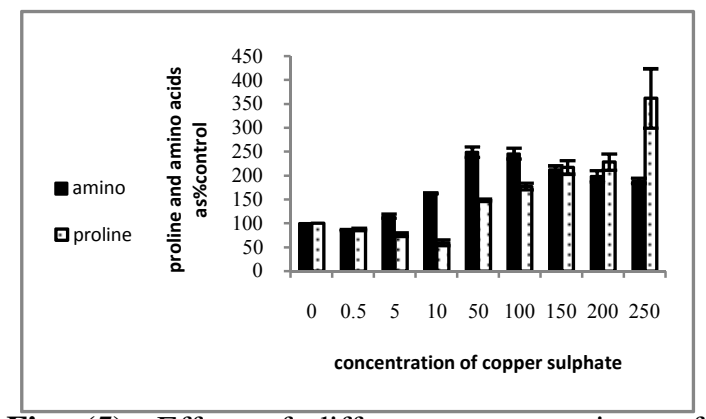

Fig. (5): Effect of different concentrations of cupper ion on the percentage control of proline and amino acids of Ankistrodesmu falcatus.

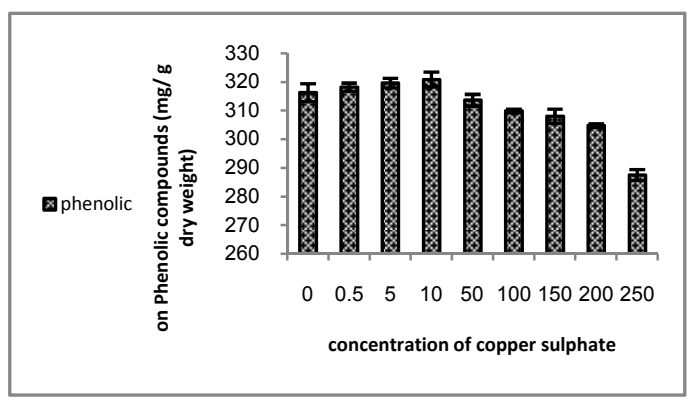

Fig. (6): Effect of different concentrations of cupper ion on phenolic compounds $\mu \mathrm{gm} / \mathrm{mg}$ dry Weight of Ankistrodesmus falcatus 


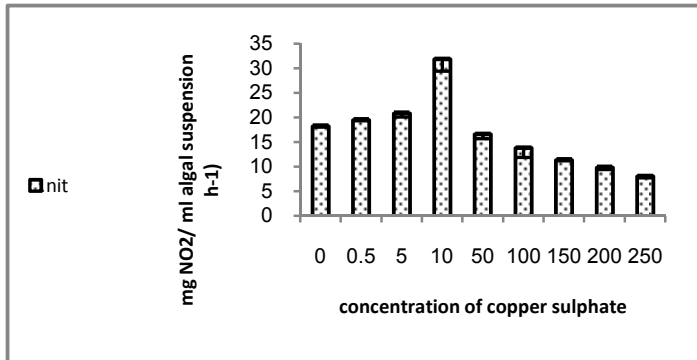

Fig. (7): Effect of different concentrations of cupper ion on nitrate reductasemg $\mathrm{NO}_{2} / \mathrm{ml}$ algal suspension $\mathrm{h}$ $\left.{ }^{1}\right)$ Ankistrodesmus falcatus.

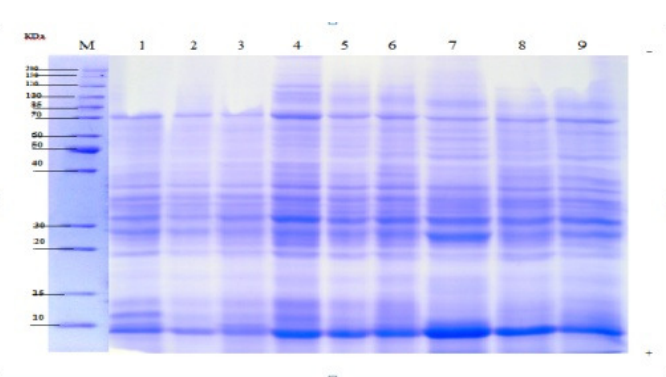

Fig. 8: Comassie-stained SDS-10\% polyacrylamide gel of polypeptides of Ankistrodesmus falcatus treated with different concentrations of cupper $(0.0 \mu \mathrm{m}$, lane $1 ; 0.5$ $\mu \mathrm{m}$, lane2; $5 \mu \mathrm{m}$, lane3; $10 \mu \mathrm{m}$, lane 4 and $50 \mu \mathrm{m}$, lane 5,100 lane 6) 150 lane 7,200 lane8 and 250 lane 9.

\begin{tabular}{|c|c|c|c|c|c|c|c|c|c|c|}
\hline \multirow[t]{2}{*}{ No. Of band } & \multirow[t]{2}{*}{ M. Wt. } & \multicolumn{7}{|c|}{ Cu conc. $(\mu \mathrm{m})$} & \multirow[b]{2}{*}{200} & \multirow[b]{2}{*}{250} \\
\hline & & Contr. & 0.5 & 5 & 10 & 50 & 100 & 150 & & \\
\hline 1 & 208 & & & & & + & + & + & + & + \\
\hline 2 & 165 & & & & + & + & + & + & + & + \\
\hline 3 & 141 & & & & & & + & + & + & + \\
\hline 4 & 118 & & & & + & + & + & + & + & \\
\hline 5 & 117 & & & & & & & & + & + \\
\hline 6 & 100 & & & & & + & + & + & + & + \\
\hline 7 & 96 & & & + & + & & + & + & + & + \\
\hline 8 & 92 & & & & & & & & + & + \\
\hline 9 & 89 & & & & & & & & & \\
\hline 10 & 85 & & & + & + & + & + & + & + & + \\
\hline 11 & 74 & & & & + & + & + & + & + & + \\
\hline 12 & 73 & & + & + & + & + & + & & + & + \\
\hline 13 & 71 & & & & & + & + & + & + & + \\
\hline 14 & 70 & + & + & & + & & & & + & + \\
\hline 15 & 69 & & & & + & & & & + & \\
\hline 16 & 67 & & & + & + & + & + & + & + & + \\
\hline 17 & 66 & & & & + & ${ }^{+}$ & & & + & \\
\hline 18 & 64 & + & + & + & + & & + & + & + & + \\
\hline 19 & 63 & & & & & & & + & 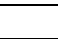 & + \\
\hline 20 & 62 & 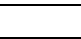 & & 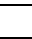 & 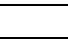 & & & & & + \\
\hline 21 & 60 & + & & + & + & & 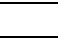 & + & & \\
\hline 22 & 59 & 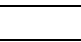 & - & & & + & + & + & + & + \\
\hline 23 & 58 & + & + & + & + & & & . & + & ${ }^{+}$ \\
\hline 24 & 53 & & & & & & & + & + & \\
\hline 25 & 50 & & & & & + & + & & & \\
\hline 26 & 49 & & + & + & & + & + & + & + & + \\
\hline 27 & 46 & + & + & + & + & + & + & + & + & \\
\hline 28 & 45 & + & + & + & + & & + & + & & + \\
\hline 29 & 42 & + & + & + & + & ${ }^{+}$ & + & + & + & + \\
\hline 30 & 41 & & & & & & & & & \\
\hline 31 & 40 & 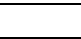 & & & & & + & & + & + \\
\hline 32 & 39 & + & & & & & & & 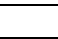 & 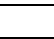 \\
\hline 33 & 38 & & & & & & & + & + & + \\
\hline 34 & 37 & + & + & + & + & + & + & + & + & + \\
\hline 35 & 36 & + & + & + & + & + & + & + & + & + \\
\hline 36 & 35 & & & & & & & & & \\
\hline 37 & 34 & & & & & + & + & + & + & + \\
\hline 38 & 33 & + & + & & & ${ }^{+}$ & + & + & + & ${ }^{+}$ \\
\hline 39 & 32 & & & + & + & & & & & \\
\hline 40 & 31 & & & & & + & + & + & + & + \\
\hline 41 & 28 & + & + & + & + & + & + & + & + & \\
\hline 42 & 26 & & & & & & & & + & ${ }^{+}$ \\
\hline 43 & 24 & & & & & & & & & + \\
\hline 44 & 22 & & & & & ${ }^{+}$ & + & + & + & ${ }^{+}$ \\
\hline 45 & 21 & & & & & & & & & \\
\hline 46 & 19 & + & + & + & + & + & + & + & + & + \\
\hline 47 & 18 & + & & & & & & & & + \\
\hline 48 & 16 & & & & & & & & & \\
\hline 49 & 15 & + & + & + & + & + & + & + & + & + \\
\hline \multicolumn{2}{|r|}{ Total } & 15 & 14 & 17 & 22 & 24 & 26 & 29 & 35 & 35 \\
\hline
\end{tabular}

Table (1): Molecular weights of protein bands detected in Ankistrodesmus falcatus treated with heavy metals. Data were obtained by Total Lab version 1.10 electrophoresis data system program 


\section{Discussion:}

The most important feature of this work that Ankistrodesmus falcatus can survive up to $250 \mu \mathrm{m} \mathrm{cu}^{+2}$. More ever growth criteria (cell number, dry weight and photosynthrtic pigments estimated progressively up to 10 $\mu \mathrm{m} \mathrm{cu}{ }^{+2,}$ the dry matter content nearly doubled at $10 \mu \mathrm{m} \mathrm{cu}{ }^{+2}$,then gradually reduction was obtained in this growth parameter at copper concentration increased in culture media. This mean that:

I- Ankistrodesmus falcatus tolerate the relatively high concentration of copper in nature.

II- It posses high ability to picked up a lot amount of $\mathrm{cu}$ under the polluted conditions.

III- consequently, it possesses a high capacity to clean up the copper polluted places (ponds and canals), accordingly

Ankistrodesmus

falcatus can used as an excellent biological cleaner in polluted water.

Such biphasic responses to copper were also revealed by other investigators using some plants and algae. Fageria (2002). reported that copper application significantly increased dry matter yield of upland rice and common bean. However, dry matter yields of the two species were decreased at the highest $\mathrm{Cu}$ concentrations.

Gao et al., (2008). working on Jatropha curcas L. Seedlings found that the biomass in leaves increased slightly at lower $\mathrm{Cu}$ concentrations. There was a correlation between increasing $\mathrm{Cu}$ concentration and reduced seedling stems and roots mass. Lara and Luca (2005). reported that the peach root stock prunus cerasifera Mr.S. 2/5 plantlets grown in vitro on media containing either 10 or $50 \mu \mathrm{m}$ of cuso 4 did not show any visible signs of copper toxicity. The negative effect of $\mathrm{Cu}+2$ on photosynthetic pigments in algae had been reported by (Dewez et al., 2005; Perales-Vela et al., 2007).

Copper tolerance of Ankistrodesmus falcatus was founded to be linked with the stable levels of carbohydrates and proteins even at the highest copper levels used. This mean that copper made Ankistrodesmus falcatus able to unregulate the interaction between carbon and nitrogen which might used as suitable marker for the copper tolerance of Ankistrodesmus falcatus.this was linked with the marked and progressive accumulation of soluble protein which detoxify the copper toxicity(phytochelation) along with this amino acids and proline increased unexpectedly by copper. Amino acids approach to fold as the severe doses of copper. More ever proline content was fold at the highest doses of copper which indicated that this huge accumulation of amino acids and proline could play the major role in detoxification of copper and might responsible for increasing the copper tolerance of ankistrodesmus falcatus.

Such enhancement of amino acids and including proline content by metal stress is a common metabolic response of algae (ElNaggar, 1993). The mechanisms of proline action are not fully under stood, but it has been suggested that increased accumulation permits osmotic adjustment, as well as provides protection for enzymes (Sharma et al., 1998, Basake et al., 2001). Biological membranes and polyribosome. Proline is capable of detoxifying free radicals by forming a stable complex with them, thus maintaining NAD $(\mathrm{P})+/ \mathrm{NAD}(\mathrm{P}) \mathrm{H}$ ratios during stress at values similar to normal conditions (Hare and Cress, 1997; Floyd and Nagy, 1984).

The data also reveal that Phenolic compound in Ankistrodesmus falcatus did not affected at any copper levels. They remained around the control value. Phenolic compound might used as antioxidant compound for scavenging the reactive oxygen species in alga and higher plant (Burritt et al., 2002; Contreas et al., 2005).

The activity of nitrate reductase stimulated markedly up to $10 \mathrm{~mm}$, there is quick increase in the activity of nitrate reductase as the level of $10 \mathrm{~mm}(174.3 \%)$ (the same level which nearly doubled the dry matter content) then this activity began to decrease gradually which was more pronounced only at the severe doses of copper. This criteria in the activity of nitrate reductase could help this alga to kept its protein content even at the severe doses of copper.

The inhibition of Nitrate reductase activity in Ankistrodesmus at severe copper stress is likely due to impaired NO3- uptake in the presence of elevated levels of the test 
metals. The other possibility could be direct inhibition of N-R activity by the test metals (De Filippis and Pallaghy, 1994). Proteins did not affected with the pronounced drop in the activity of Nitrate reductase especially at the higher doses of the inhibitor. This might indicated that, the two processes (the activity of Nitrate reductase and the machinery of protein synthesis) did not necessary linked (Abdel Rahman et al., 2004).

the data of protein pattern reveal that:

1- the total number of polypeptides increased progressively as the copper concentration increased in the culture media. For example the number of polypeptides at the higher doses of cu $\left(200 \mu \mathrm{m} \mathrm{Cu}^{+2}\right.$ and $\left.250 \mu \mathrm{m} \mathrm{Cu}^{+2}\right)$ were 35 compared to only 15 in the control.

2- thus a huge number of polypeptides appeared due to cu stress.

3- the new polypeptides which induced by $\mathrm{cu}$ stress scattered from a very high molecular weight polypeptides to very low molecular weight polypeptides. Interesting the highest molecular weight 208 K.Da appeared when the growth began to be reduced (the level of $50 \mu \mathrm{m}$ $\mathrm{Cu}^{+2}$ and higher).while the 165 and 118 K.Da appeared from 10 to 200 $\mu \mathrm{mcu}^{+2}$.comulatively it is worth to mention that, the more higher molecular weight of protein(208-73 K.Da) appeared in the copper treated media. Thus one can say that all of those polypeptides considered a copper polypeptides . also the lower molecular weight polypeptides (22 K.Da) which considered a heat chock protein appeared only at the level from 50 to $250 \mu \mathrm{m} \mathrm{cu}^{+2}$.

\section{Conclusion}

According to the above result and discussion it can be concluded that Ankistrodesmus falcatus exerted surprising copper tolerance:

I- The growth criteria was stimulated unexpectedly up to $10 \mu \mathrm{m} \mathrm{cu}^{+2}$.

II- it can survived up to the relative higher doses of copper $\left(250 \mu \mathrm{m} \mathrm{cu}^{+2}\right)$.

III- which intern induce the ability of this alga to picked the a lot amount of copper under the polluted condition. consequently it posses a high capacity to clean up the copper polluted places( ponds and canal), accordingly
Ankistrodesmus falcatus can used as an excellent biological cleaner in polluted water.

\section{Refrences:}

Abdel-Rahman, M.H.M., Ali, R.M. and Said, H.A. (2004). Soil algae in different habitats at El Fayoum Governorate (Egypt). Egypt. J. Biotechnol., 18: 170-183.

Andrade, I.R., Farina, M. and Filho, A.M.G. (2004). Effects of copper on Enteromorpha flexuosa (Chlorophyta) in vitro. Ecotox. Environ. Safe, 58: 117-125.

Basak, M., Sharma, M. and Chakraborty, U. (2001). Biochemical responses of Camellia sinensis (L.) O. Kuntze to heavy metal stress, J. Environ. Biol., 22: 37-41.

Bates, L.S., Waldren R.P. and Teare, I.D. (1973). Rapid determination of free proline for water-stress studies, Plant Soil, 39: 205-207.

Broadley, M.R., White, P.J., Hammond, J.P., Zelko, I., Lux, A. (2007). Zinc in plants,new phytol.173: 677-702.

Burritt, D.J., Larkindale, J. and Hurd, K. (2002). Antioxidant metabolism in the intertidal red seaweed Stiosiphonia arbuscula following desiccation. Planta, 215: 829-838.

Campbell, W.H. (1999). Nitrate reductase structure, function and regulation: bridging the gap between biochemistry and physiology. Annu. Rev. Plant. Physiol. Plant. Mol. Biol. 50: 277-303.

Contreras, L., Moenne, A. and Correa, J. (2005). Antioxidant responses in Scytosiphon lomentaria (phaeophyta) inhabiting copper enriched coastal environments. J. Physiol., 41: 1184-1195.

Dai, G.H., Andary, C., Cosson, L.M. And Boubals, D. (1994). Polyphenols and resistance of grapvienes (Vitis spp.) To downy mildew (Plasmoparaviticola). Acta. Horticulture, 381: 763-766.

De Filippis, L.F. and Pallaghy, C.K. (1994). Heavy metals: sources and biological effects. In: Rai LC, Gaur JP, Soeder CJ (eds) Algae and Water Pollution. E. Schweizerbart'scheVerlagsbuchhandlun g, Stuttgart, pp 31-77.

Dewez, D., Geoffroy, L., Vernet, G. and Popovic, R. (2005). Determination of 
photosynthetic and enzymatic biomarkers sensitivity used to evaluate toxin effects of copper and fludioxonil in alga Scenedesmusobliquus. Aquat. Toxicol, 74: 150-159.

Dewez, D., Geoffroy, L., Vernet, G. and Popovic, R. (2005). Determination of photosynthetic and enzymatic biomarkers sensitivity used to evaluate toxin effects of copper and fludioxonil in alga Scenedesmusobliquus. Aquat. Toxicol, 74: 150-159.

Fageria, N.K. (2002), Influence of micronutrients on dry matter yield and interaction with other nutrients in annual crops. Pesq.Agropec.Bras.,Brasilis，37: 17651772.

Fales, F.W. (1951). The assimilation and degradation of carbohydrates by yeast cells. J. Biol. Chem., 193: 113-124.

Fernandes, J.C. and Henriques, F.S. (1991). Biochemical, physiological and structural effects of excess copper in plants. Bot. Rev., 57: 246-273.

Floyd, R.A. and Nagy, Z.S. (1984). Formation of long lived hydroxyl free radical adducts of proline and hydroxyproline in Fenton reaction, Biochem. Biophys. Acta, 790: 94-97.

Gao, S., Yan, R., Cao, M., Yang, W., Wang, S. And Chen, F. (2008). Effects of copper on growth, antioxidant enzymes and phenylalanine ammonia-lyase activities in Jatrophacurcus L. Seedlings. Plant Soil Environ, 54(3): 117-122.

Hare, P.D. and Cress, W.A. (1997). Metabolic implications of stress-induced proline accumulation in plants. Plant Growth Regul, 21: 79-102.

Hare, P.D. and Cress, W.A. (1997). Metabolic implications of stress-induced proline accumulation in plants. Plant Growth Regul., 21: 79-102.

Jaworski, E.G. (1971). Nitrate reductase assay in intact plant tissues, Biochem.ophys.Res. Commun, 43: 1274-1279.

Klobus, G., Burzynski, M. And Buczek, J. (2002). Heavy metals and nitrogen metabolism. In: Prasad MNV, Strazalka K (eds) Physiology and Biochemistry of Metal Toxicity and Tolerance in Plants. Kluwer Academic Publishers, The Netherlands, pp 325-355.

Kobbia, I.A. and Shabana, E.F. (1988). Studies on soil algal flora of Egyptian Bahriya Oasis. Egypt. J. Bot., 31: 23-43.

Lara, L. And Luca, S. (2005). Copper toxicity in Prunuscerasifera: growth and antioxidant enzymes responses of in vitro grown plants. Plant Science, 168: 797-802.

Lowry, O.H., Rosebrough, N.S. Farr A.L. and Randall, R.J. (1951). Protein measurement with the Folin-phenol reagent, J. Biol. Chem., 193: 265--275.

Ma, M., Zhu, W., Wand, Z. and Witkamp, G. (2003). Accumulation, assimilation and growth inhibition of copper on fresh water alga Scenedesmussubspicatus 86.81 SAG) in the presence of EDTA and fulvic acid. Aquat.Toxicol, 63: 221228.

Mallick, N. and Mohn, F.H. (2003). Use of chlorophyll fluorescence in metal stress research: a case study with the green Microalga scenedesmus. Ecotox. Environ. Safe, 55: 64-69.

Metzner, H., Rau, H. and Singer, H. (1965). untersuchungenzursynchronisierbarkeite inzelnerPigmentmangelMutanten von Chlorella.Planta, 65: 186-94.

Moore, S., Spachman, D.H., Steins, W. (1958). Chromatography of amino acids on sulphonated polystyrene resins. Anal. chem. 30: 1185.

Nagalakshmi, N. and Prasad, M.N.V. (1998). Copper-induced oxidative stress in Scenedesmusbijugatus: protective role of free radical scavengers. Bull. Environ. Contam.Toxicol, 61: 623-628.

Nalewajko, C. and Olaveson, M.M. (1995). Differential responses of growth, photosynthesis, respiration and phosphate uptake to copper in coppertolerant and copper-intolerant strains of Scenedesmusacutus (Chlorophyceae). Can. J. Bot., 73: 1295-1303.

Perales-Vela, H.V., Gonzalez-Moreno, S., Montes-Horcasitas, C. and CanizaresVillanueva, R.O. (2007). Growth, photosynthetic and respiratory responses to sub-lethal copper concentrations in Scenedesmusincrassatulus (Chlorophyceae). Chemosphere, 67: 2274-2281.

Perales-Vela, H.V., Gonzalez-Moreno, S., Montes-Horcasitas, C. and CanizaresVillanueva, R.O. (2007). Growth, photosynthetic and respiratory responses to sub-lethal copper concentrations in Scenedesmusincrassatulus (Chlorophyceae). Chemosphere, 67: 2274-2281.

Rai, P.K., Mallick, N. and Rai, L.C. (1994). Effect of $\mathrm{Cu}$ and $\mathrm{Ni}$ on growth, mineral uptake, photosynthesis and enzyme 
activities of Chlorella vulgaris. Biomed. Environ. Sci., 7: 56-67.

Rippka, R., Derulles, J., Waterburry, J.B., Herdman, M. and Stanier, P.Y. (1979). Generic Assignments, strain histories and pure cultures of Cyanobacteria.J.Gen.Microbiol 111, 161.

Rout, G.R., Das, P. (2003). Effect of metal toxicity on plant growth and Satoh, A.; Vudikaria, L.Q., Kurano, N. And Myiachi, S. (2005). Evaluation of the sensitivity of marine microalgae strains to the heavy metals, $\mathrm{Cu}, \mathrm{As}, \mathrm{Sb}, \mathrm{Pd}$ and Cd. Environ. Int., 31: 713-722.
Shaddad, M.A., Radi, A.F., Abdel-Rahman A.M. and Azooz, M.M. (1990). Response of seeds of Lupinustermis and Vicia faha to the interactive effect of salinity and ascorbic acid or pyridoxine. Plant and Soil, 122: 177-183.

Teisseire, H. and Guy, V. (2000). Copperinduced changes in antioxidant enzymes activities in fronds of duckweed (Lemna minor). Plant Sci., 153: 65-72

Utting, S.D. (1985). Influence of nitrogen availability on the biochemical composition of three unicellular marine algae of commercial importance. Aquacult. Eng., 4: 175-190.

أجريت هذه الدر اسة لمعرفة تأثثر النحاس على نمو و على بعض التغيرات الفسيولوجية لطحلب الانكستروديسمس فالكاتس

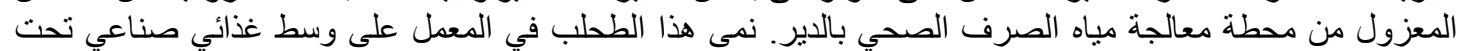

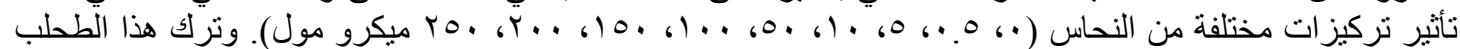

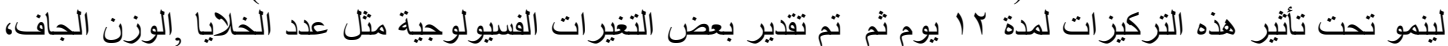

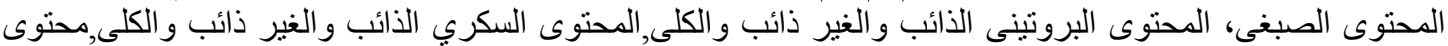

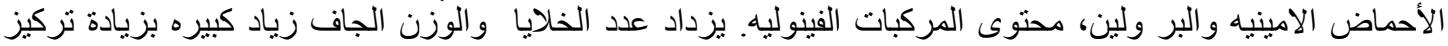

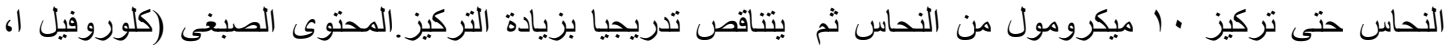

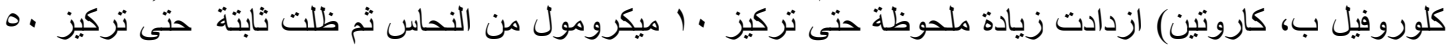

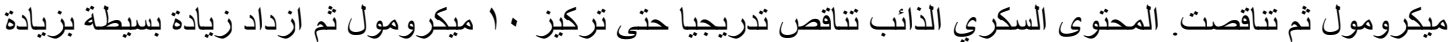

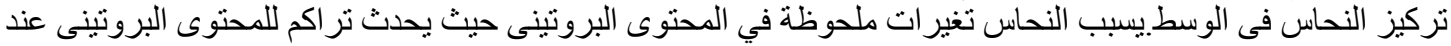

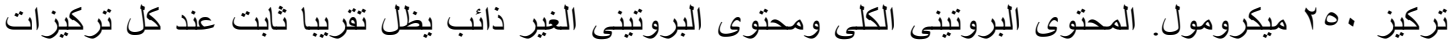

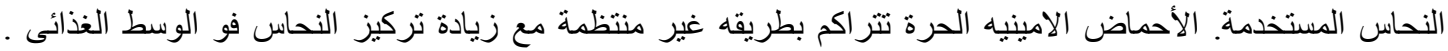

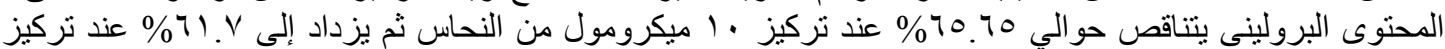
• O Y ميكرومول. محتوى المو اد القينوليه لا يتاثر بزيادة تركيز النحاس. 